\title{
Mirror Syndrome after Fetoscopic Laser Treatment - A Case Report
}

\section{Síndrome do espelho após tratamento laser por fetoscopia - caso clínico}

\author{
Ana Maria Simões Brandão ${ }^{1}$ Ana Patrícia Rodrigues Domingues ${ }^{1}$ Etelvina Morais Ferreira Fonseca ${ }^{1}$ \\ Teresa Maria Antunes Miranda ${ }^{1}$ José Paulo Achando Silva Moura ${ }^{1}$ \\ 1 Obstetrics Unit A, Maternidade Dr. Daniel de Matos, Centro \\ Hospitalar e Universitário de Coimbra (CHUC), Faculdade de \\ Medicina, Universidade de Coimbra, Portugal \\ Rev Bras Ginecol Obstet 2016;38:576-579. \\ Address for correspondence Ana Brandão, Medical Resident, Rua \\ Miguel Torga, 3030-165 Coimbra, Portugal \\ (e-mail: anam_brandao@hotmail.com; \\ secobstetricia@huc.min-saude.pt).
}

\begin{abstract}
Mirror syndrome is a rare disease with unknown pathophysiology that can be present in different diseases that can cause fetal hydrops. The prognosis is usually bad with a high

Keywords

- mirror syndrome

- fetoscopic laser treatment

- twin-twin transfusion syndrome perinatal mortality. We report an unusual form of mirror syndrome that manifested itself only after a successful treatment for fetal hydrops (caused by twin-twin transfusion syndrome, in Quinteros stage IV) was performed. This syndrome was controlled by medical treatment, and despite the usually bad prognosis seen in these cases, we could extend the pregnancy from the 23rd to the 34th week of gestation, resulting in the birth of 2 live infants.

\section{Resumo}

\section{Palavras-chave}

- síndrome do espelho

- tratamento a laser fetoscópico

- síndrome de transfusão feto-fetal

A síndrome do espelho é uma doença rara, de fisiopatologia desconhecida, que se manifesta em situações obstétricas responsáveis pela presença de hidrópsia fetal. Habitualmente o prognóstico é reservado, uma vez que se associa a elevadas taxas de mortalidade perinatal. O presente caso clínico trata de uma situação de síndrome do espelho que se manifestou, atipicamente, após o tratamento eficaz para a hidrópsia fetal associada à síndrome de transfusão feto-fetal.

Apesar do mau prognóstico associado a estas situações, conseguiu-se controlar a situação apenas com tratamento médico e, desta forma, prolongar a gravidez durante 12 semanas.
\end{abstract}

\section{Introduction}

Mirror syndrome, also called Ballantyne's or triple edema syndrome, was described in 1982 by John Ballantyne as a combination of maternal edema, fetal and placental hydrops. This syndrome is a complication of fetal hydrops in which the maternal edema virtually mirrors the edema of the fetus. The incidence is not clear since it is a rare disease, often underdiagnosed. ${ }^{1-3}$

Fetal hydrops of any etiology, immune and nonimmune ( - Table $\mathbf{1}$ ), can be associated with mirror syndrome, which appears when fetal symptoms become severe. Nevertheless, received

May 19, 2016

accepted

September 27, 2016
DOI http://dx.doi.org/ $10.1055 / \mathrm{s}-0036-1593895$. ISSN $0100-7203$.
Copyright $\odot 2016$ by Thieme-Revinter

Publicações Ltda, Rio de Janeiro, Brazil
License terms

(c) $(1) \$$ 
Mirror Syndrome after Fetoscopic Laser Treatment - A Case Report Brandão et al. 577

Table 1 Different causes associated with mirror syndrome

\begin{tabular}{|l|l|l|}
\hline Immune & Rh iso immunization & Parvovirus B19 \\
\cline { 3 - 3 } & Viral infections & Human parvovirus \\
\cline { 2 - 3 } & & Coxsackie virus \\
\cline { 2 - 3 } & Structural fetal or placental malformations & Sacrococcygeal teratoma \\
\cline { 2 - 3 } & & Aneurysm of Galen's vein \\
\cline { 2 - 3 } & Ebstein's anomaly \\
\cline { 2 - 3 } & Multiple pregnancy & Placental chorioangioma \\
\cline { 2 - 3 } & Fetal arrhythmia & Twin-twin transfusion syndrome \\
\hline
\end{tabular}

the syndrome's pathogenesis and pathophysiology are still unknown, and it is associated with a high perinatal mortality. $^{1-5}$

According to a few cases described in the literature, the gestational age of appearance of this syndrome ranges from 22 to 29 weeks. ${ }^{2,4}$ However, other reports suggest a sporadic earlier or later gestational age of manifestation. ${ }^{2,6}$

Symptoms of maternal edema include weight gain; elevated blood pressure with or without proteinuria; oliguria; tachycardia and tachypnea; acute respiratory failure due to pulmonary edema; and laboratorial signs of hemodilution with mild anemia and elevated liver enzymes, thus resembling other complications such as preeclampsia or HELLP syndrome. ${ }^{1,3,7}$ It has been suggested that the presence of hemodilution might be an important criterion to better differentiate mirror syndrome from preeclampsia, which is associated with hemoconcentration. ${ }^{3,8}$

The similarity between these diseases has led some authors to designate mirror syndrome as a preeclampsialike syndrome. ${ }^{7}$ Several studies and case reports have emerged in which authors have focused on a possible placental dysfunction, where upregulation of antiangiogenic factors seems to be responsible for the preeclampsia-like clinical pictures seen in mirror syndrome. , $^{3,7-9}$

Mirror syndrome can be reversible when the underlying factors are identified and corrected. ${ }^{3}$ Improvement in the maternal condition after treating the cause of fetal hydrops has been reported. ${ }^{10}$ When it is not possible to reverse the main factor, the prognosis of the syndrome is usually poor, with high perinatal mortality, and prompt termination of pregnancy is often recommended. ${ }^{11}$ Delivery, of course, should be in accordance with gestational age and maternal stability. ${ }^{3}$ Support therapy (diuretics and antihypertensive therapy) for maternal stability is crucial in preventing the deterioration of the mother's condition.

Mirror syndrome is also a rare complication of twin-twin transfusion syndrome (TTTS), a severe complication associated with monochorionic twin pregnancies due to the unbalanced flow of blood from one twin (donor) to its co-twin (recipient) through arteriovenous anastomoses deep within the shared placental lobules. ${ }^{5,8}$ It is a progressive disease, essentially hemodynamic, with implications for the cardiovascular systems of both twins, presenting itself more severely in the recipient twin, who usually has a progressive cardiomyopathy as an adaptive fetal response to hemodynamic, hormonal and biochemical stressors. ${ }^{12,13}$

Fetoscopic laser ablation of the placental anastomoses is the primary treatment of TTTS, having a deep effect on fetal hemodynamics and on the reversal of cardiac dysfunction and valvulopathy, even in severe cases. ${ }^{5,9,13}$ When mirror syndrome complicates TTTS, the laser treatment also has the potential to reverse this complication. ${ }^{8}$ So far, there have been very few cases reported in the literature in which mirror syndrome occurred after laser therapy for TTTS. ${ }^{5,11,14}$ We report one such unusual case in which mirror syndrome presented itself only after fetoscopic laser therapy was done for fetal hydrops in a twin gestation.

\section{Case Report}

A 38 year-old woman with a spontaneous monochorionic, diamniotic twin pregnancy was referred to our institution at 9 weeks for a multiple pregnancy follow-up. Her personal medical history included ankylosing spondylitis and hypersomnia, a B Rh-positive blood type, and a previous forceps and breech delivery (gesta 3 para 2). An amniocentesis was performed for advanced maternal age, and it revealed a normal karyotype in both fetuses. The first ultrasounds were normal, although on the 16th week, a minimal difference in amniotic fluid was found between both fetuses. This difference was maintained on subsequent weeks (maximum vertical pocket of 2.4 versus $7.4 \mathrm{~cm}$ ), but without the criteria of a TTTS.

At 23 weeks of gestation, an ultrasound showed acute fetal deterioration with oligohydramnios versus polyhydramnios, discordant bladders, and the recipient twin presented severe hydrops and cardiomegaly (-Fig. 1). The diagnosis of TTTS in Quintero stage IV was made. Umbilical artery Doppler flow indices were abnormal (altered pulsatility index) in the recipient twin, and his echocardiogram showed a cardiomegaly with reduced cardiac ejection fraction and a narrow aorta. 

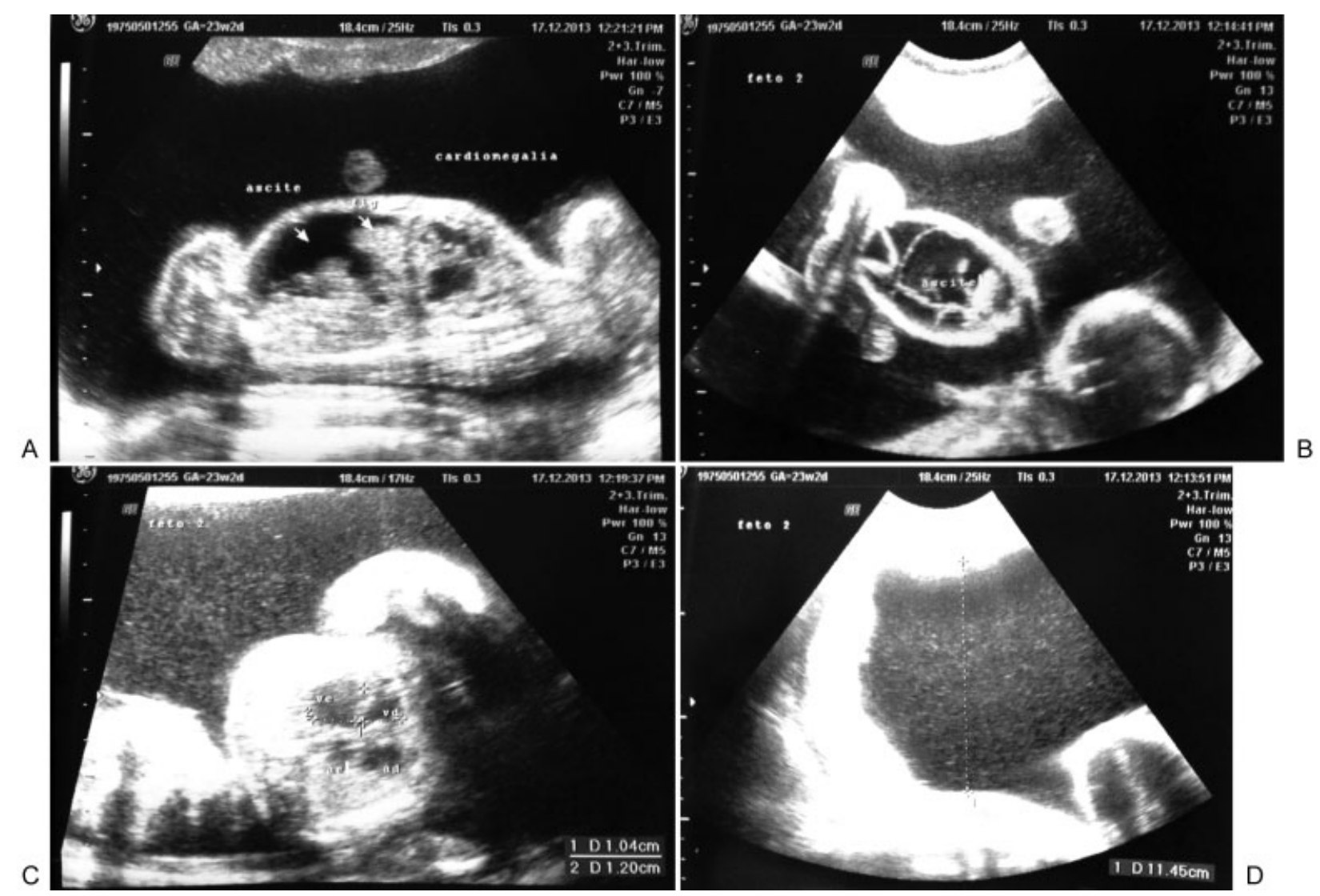

Fig. 1 Ultrasound findings of the fetus with hydrops (A and B), cardiomegaly (C) and polydramnios (D).

Since our institution does not have experience with laser treatment for TTTS, we contacted and sent the gravid to the Clínic Barcelona Hospital Universitari, where a successful fetoscopic laser therapy was performed. The mother and the fetuses responded well on the first hours after this procedure. However, on the day after, the mother presented an acute shortness of breath in a context of intense generalized edema and oliguria, without signs of hypertension or proteinuria. Analytically, she presented a progressive dilutional anemia (hemoglobin $[\mathrm{Hgb}]=8.3 \mathrm{~g} / \mathrm{dL}$; hematocrit [Htc] $=25.7 \%)$, normal renal function $\left(\mathrm{Na}^{+}=134\right.$; creatinine $=0.47$ ), normal hepatic function, and negative protein to creatinine ratio in urine (0.3). Diuretics (furosemide three times a day ) were introduced into the mother's therapy.

Four days afterward, she was discharged and arrived clinically stable at our obstetrics unit, where diuretics treatment, clinical and analytical controls were maintained for another five days. Having recuperated, she was discharged from our hospital, but stayed on weekly ambulatory fetomaternal controls (clinical and ultrasound controls). The exrecipient fetus had a persistent cardiomegaly, with echocardiograms showing an improvement, but maintaining left ventricular systolic dysfunction.

At 34 weeks, the mother presented new breathing difficulties, accompanied by edema of the face and lower limbs. A cesarean section was performed. Two live infants were delivered, males weighing 2,085 and 2,070 g each, with an APGAR score of 9/10/10.
The postnatal echocardiogram of the ex-recipient twin showed biventricular hypertrophy and distal dilatation of the left ventricle with contraction anomaly and hypertrabeculation. Twenty months later, this twin presents no cardiac symptoms and has a normal cardiac auscultation, with an echocardiogram revealing lateral and apical trabeculation but a normal ejection fraction. The ex-donor twin has no cardiac problem.

Despite the physical development being good in both twins, they are manifesting some delayed motor development: sitting without support only at 13 months and walking at 17 months.

\section{Discussion}

Mirror syndrome is a rare condition, where maternal edema mirrors the fetal and placental hydrops. Many causes have been associated with this syndrome, mainly those that are known to cause fetal hydrops.

Our case was an unusual form of mirror syndrome because its trigger was not the primary cause of fetal hydrops. This syndrome only manifested after a successful laser treatment for placental anastomoses, in a context of TTTS (Quintero stage IV). In the literature, there are three cases of mirror syndrome related with laser treatment for TTTS, but all of them with a hydropic donor, and all needed delivery in a short term to resolve the syndrome. Only in one case both twins survived, while in the other cases, just one twin 
survived. ${ }^{5,11,14}$ In our report, the receiver twin was the hydropic. The mirror syndrome was controlled by medical treatment alone, and there was no need for doing an emergency C-section.

Preeclampsia syndrome was the differential diagnosis proposed, but the mirror syndrome was a more probable diagnosis, due to the presence of hemodilutional anemia without high blood pressure. The early gestational age of our case (24 weeks) also supported this diagnosis.

Fortunately, despite the increase in perinatal mortality usually associated with both mirror syndrome and TTTS in stage IV, our case evolved favorably with medical treatment, permitting us to maintain pregnancy for another 12 weeks, and successfully culminated in the delivery of 2 live infants at 34 weeks of gestation.

\section{Acknowledgment}

We would like to acknowledge the Clínic Barcelona Hospital Universitari for their support on the laser treatment performed.

\section{References}

1 Braun T, Brauer M, Fuchs I, et al. Mirror syndrome: a systematic review of fetal associated conditions, maternal presentation and perinatal outcome. Fetal Diagn Ther 2010;27(4):191-203

2 Giacobbe A, Grasso R, Interdonato ML, et al. An unusual form of mirror syndrome: a case report. J Matern Fetal Neonatal Med 2013;26(3):313-315

3 Gedikbasi A, Oztarhan K, Gunenc Z, et al. Preeclampsia due to fetal non-immune hydrops: mirror syndrome and review of literature. Hypertens Pregnancy 2011;30(3):322-330
4 Graham N, Garrod A, Bullen P, Heazell AE. Placental expression of anti-angiogenic proteins in mirror syndrome: a case report. Placenta 2012;33(6):528-531

5 Kumar B, Nazaretian SP, Ryan AJ, Simpson I. Mirror syndrome: a rare entity. Pathology 2007;39(3):373-375

6 Vidaeff AC, Pschirrer ER, Mastrobattista JM, Gilstrap LC III, Ramin SM. Mirror syndrome. A case report. J Reprod Med 2002;47(9): 770-774

7 Bixel K, Silasi M, Zelop CM, et al. Placental origins of angiogenic dysfunction in mirror syndrome. Hypertens Pregnancy 2012; 31(2):211-217

8 Prefumo F, Pagani G, Fratelli N, Benigni A, Frusca T. Increased concentrations of antiangiogenic factors in mirror syndrome complicating twin-to-twin transfusion syndrome. Prenat Diagn 2010;30(4):378-379

9 Llurba E, Marsal G, Sanchez O, et al. Angiogenic and antiangiogenic factors before and after resolution of maternal mirror syndrome. Ultrasound Obstet Gynecol 2012;40(3):367-369

10 Chang YL, Chao AS, Hsu JJ, Chang SD, Soong YK. Selective fetocide reversed mirror syndrome in a dichorionic triplet pregnancy with severe twin-twin transfusion syndrome: a case report. Fetal Diagn Ther 2007;22(6):428-430

11 Hayashi S, Sago H, Hayashi R, et al. Manifestation of mirror syndrome after fetoscopic laser photocoagulation in severe twin-twin transfusion syndrome. Fetal Diagn Ther 2006;21(1): $51-54$

12 Herberg U, Gross W, Bartmann P, Banek CS, Hecher K, Breuer J. Long term cardiac follow up of severe twin to twin transfusion syndrome after intrauterine laser coagulation. Heart 2006;92(1): 95-100

13 Habli M, Michelfelder E, Cnota J, et al. Prevalence and progression of recipient-twin cardiomyopathy in early-stage twin-twin transfusion syndrome. Ultrasound Obstet Gynecol 2012;39(1):63-68

14 Chang YL, Chao AS, Chang SD, Wang CN. Mirror syndrome after fetoscopic laser therapy for twin-twin transfusion syndrome due to transient donor hydrops that resolved before delivery. A case report. J Reprod Med 2014;59(1-2):90-92 